NOTE

\title{
Two distinctive REE abundances of Jurassic pillow lavas from the Tokoro Belt, central Hokkaido, Japan
}

\author{
SAtoshi Koshimizu and TAKeo Bamba \\ Department of Geology and Mineralogy, Faculty of Science, \\ Hokkaido University, Sapporo, 060 Japan
}

(Received January 14, 1984: Accepted March 10, 1984)

The Tokoro Belt, a tectonic unit of the central axial zone of Hokkaido, is characterized by preponderant occurrence of Jurassic pillow lavas. These pillow lavas occur separately in the Eastern and the Western masses of the northern Tokoro Belt. The pillow lavas from the Eastern mass are tholeiitic basalt which is considered to have been produced in an abyssal sea floor, while, those from the Western mass are alkali basalt probably related to the formation of seamounts in Jurassic time.

REE abundances of above two types of pillow lavas were studied and the results revealed pronounced contrasts between the two masses.

\section{INTRODUCTION}

The Tokoro Belt occupying the eastern side of the central axial zone of Hokkaido is underlain by Jurassic greenstones which are unconformably covered with Cretaceous turbidites. The lower sequence is called the Nikoro Group and the upper one the Saroma Group. The Nikoro Group forms the Eastern and the Western masses in the northern Tokoro Belt. The two masses show a distinct contrast as presented in Table 1 .

Based on the available data, pillow lavas from the Eastern mass were regarded as a product of abyssal sea floor (BАMBA, 1984), and those from the Western mass were derived from seamounts of Jurassic time (NIDA, 1983, pers. com.).

Though REE abundances of Paleozoic pillow lavas from Japan have been studied by TANAKA (1977), those of Mesozoic pillow lavas have not been reported. Thus REE abundances of pillow lavas in the two masses of the Nikoro Group were examined. The results are presented in this paper.
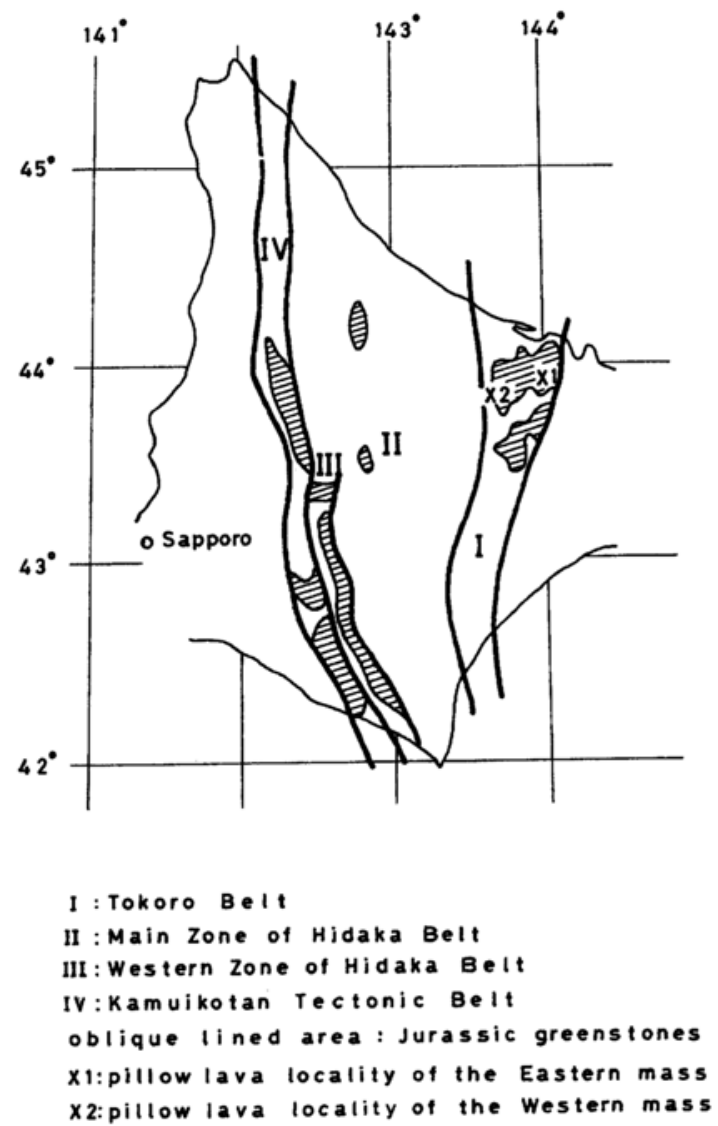

Fig. 1. Map showing the tectonic division of the Central Axial Zone of Hokkaido. The distribution of Jurassic greenstones and the localities of examined samples are also shown. 
Table 1. Comparison between the Eastern mass and the Western mass of the Nikoro Group in the northern Tokoro Belt, central Hokkaido, Japan

\section{A. Western mass}

Hyaloclastite is main constituent. Pillow lava is alkali-basalt or trachyte in which intersertal texture is overwhelming.

Limestones including coccoliths are common, and are accompanied by small amounts of radiolarian chert.

Strata-bound Mn-oxide ore deposits associated with tuffite are aligned linear parallel to massive sulfide ore deposits.

The bed strikes NS-N45 ${ }^{\circ} \mathrm{E}$ dipping eastward. Shear zone or faults are parallel to the strike and dip of the bed.

\section{Petrographic Characters of Pillow lavas}

Pillow lava from the Eastern mass Pillow lava is a main constituent in the Eastern mass of the Nikoro Group. The thickness of a unit pillow lava bed varies from ten to several tens meters, but in places, attaining several hundred meters. The pillow lavas are intercalated with radiolarian cherts and thin layers of hyaloclastites. Each pillow shows spheroidal, ellipsoidal or bowl-like forms, about $0.3-2.0$ meters in size.

The margin of a pillow is generally aphanitic, but toward the interior of the pillow, variolitic and subophitic textures made up of plagioclase

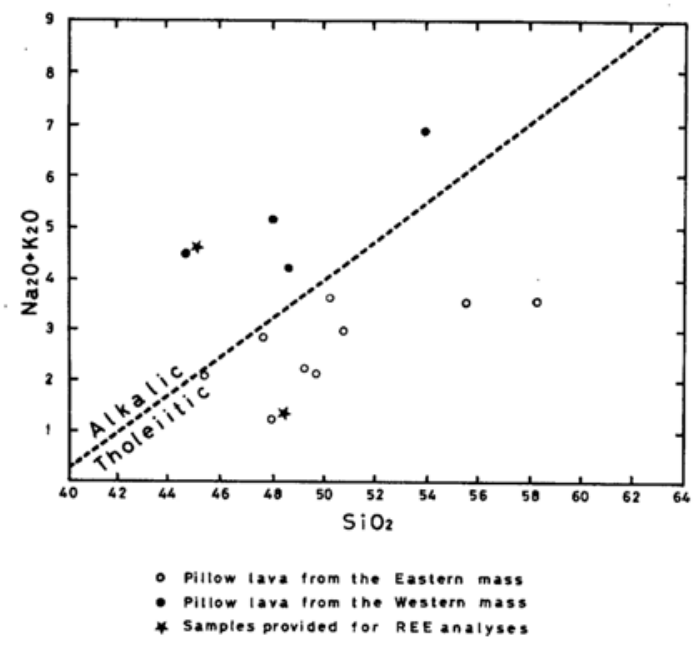

Fig. 2. Alkali-silica variations of pillow lavas from the northern Tokoro Belt. All plotted in weight percent after subtracting total water and being normalized.
B. Eastern mass

Pillow lava of tholeiitic basalt is main constituent, in which variolitic texture is prevailing. Hyaloclastite is subordinate.

Limestone is scant.

Radiolarian chert is thick and abundant.

Strata-bound manganiferous hematite deposits are abundant.

Structure of the Nikoro Group is characterized by many faults trending $\mathrm{N}-\mathrm{S}$ and $\mathrm{E}-\mathrm{W}$. These faults make the geology of this mass complicated.

and augite are observed. Ilmenite is present as an accessory mineral. Presence of chlorite, epidote, sphene, pumpellyite and calcite in the pillow lava is considered to have been formed as the products of low grade metamorphism.

Table 2. Chemical composition and CIPW norm (water free) of pillow lavas from the northern Tokoro Belt, central Hokkaido, Japan

\begin{tabular}{lrr}
\hline & \multicolumn{1}{c}{1} & \multicolumn{1}{c}{2} \\
\hline $\mathrm{SiO}_{2}$ & 45.20 & 43.01 \\
$\mathrm{TiO}_{2}$ & 1.08 & 2.77 \\
$\mathrm{Al}_{2} \mathrm{O}_{3}$ & 15.12 & 12.00 \\
$\mathrm{Fe}_{2} \mathrm{O}_{3}$ & 7.66 & 9.61 \\
$\mathrm{FeO}$ & 5.86 & 9.10 \\
$\mathrm{MnO}$ & 0.57 & 0.22 \\
$\mathrm{MgO}$ & 6.71 & 5.63 \\
$\mathrm{CaO}$ & 10.25 & 9.61 \\
$\mathrm{Na}_{2} \mathrm{O}$ & 1.13 & 3.42 \\
$\mathrm{~K}_{2} \mathrm{O}$ & 0.10 & 0.94 \\
$\mathrm{P}_{2} \mathrm{O}_{5}$ & 0.16 & 0.25 \\
$\mathrm{H}_{2} \mathrm{O}(+)$ & 5.79 & 3.42 \\
$\mathrm{H}_{2} \mathrm{O}(-)$ & 0.23 & 1.10 \\
$\mathrm{Total}$ & 99.86 & 101.08 \\
$\mathrm{q}$ & 8.54 & - \\
or & 0.65 & 5.85 \\
ab & 10.23 & 24.84 \\
an & 38.20 & 15.10 \\
ne & - & 2.77 \\
di & 11.81 & 26.08 \\
hy & 16.15 & - \\
ol & - & 4.88 \\
mt & 11.83 & 14.42 \\
il & 2.18 & 5.45 \\
ap & 0.39 & 0.60 \\
\hline & & \\
\hline
\end{tabular}

1: Pillow lava from the open-pit, Kokuriki mine, Eastern mass.

2: Pillow lava from Tomisato, Western mass. Analysts: 1; S. ITOH, 2; H. SHIMAOKA 
The bulk rock chemistry of the pillow lava in the Eastern mass shows tholeiitic as presented in Table 2 and Fig. 2.

\section{Pillow lava from the Western mass}

The Western mass of the Nikoro Group is composed mainly of hyaloclastite. Consequently, pillow lava is subordinate in this mass. A pillow, 2.0 meters in diameter, has been examined petrographically as well as chemically from the rim to the core. The rim of the pillow is $2 \mathrm{~mm}$ thick and shows greasy luster and aphanitic texture. The mantle of the pillow shows variolitic texture including a moderate amount of amygdules filled with chlorite and calcite. The varioles are composed of radiating crystals of acicular plagioclase and clinopyroxene. The core is coarse-grained and shows intersertal texture made up of plagioclase and clinopyroxene. Porphyritic texture by the presence of plagioclase and olivine phenocrysts is sometimes observed in the mantle and core of the pillow. Pillow lavas of trachytic basalt are also found in the Western mass.

The bulk rock chemistry of the pillow lava in the Western mass indicates that this is alkali basalt as presented in Table 2 and Fig. 2.

\section{Ree Abundances of the Pillow Lavas}

Trace element abundances of the pillow lavas from the two masses of the northern Tokoro Belt have been determined by instrumental neutron activation analysis (INAA) as described by Koshimizu (1984).

The samples of bulk rocks were irradiated with U.S. Geological Survey standard samples (G-2, AGV-1) (FLANAGAN, 1969) at neutron flux of $5 \cdot 10^{11} \mathrm{ncm}^{-2} \mathrm{~s}^{-1}$ for 24 hours in a TRIGA Mark II Reactor at the Institute for Atomic

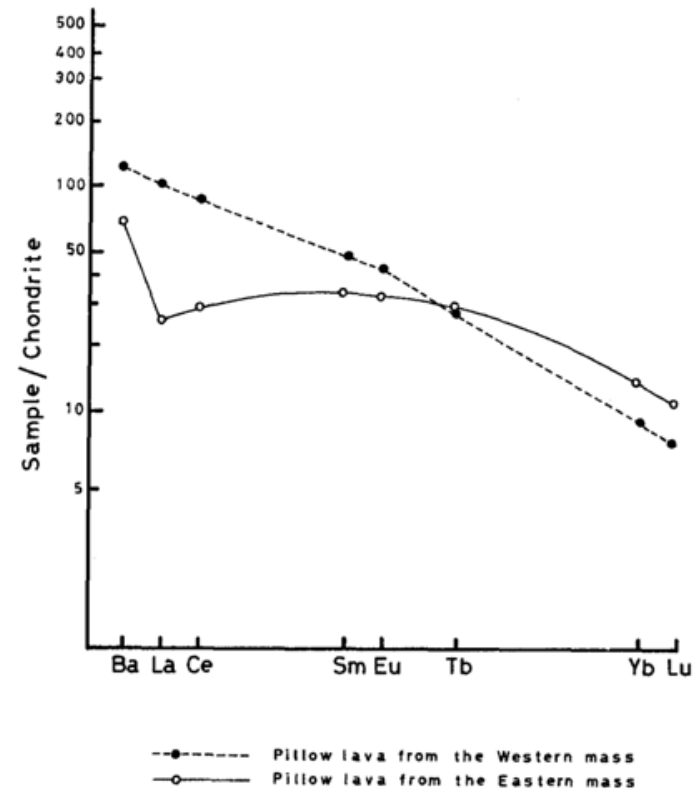

Fig. 3. Chondrite-normalized REE patterns of Jurassic pillow lavas from the northern Tokoro Belt, central Hokkaido.

Energy, Rikkyo University. Counting was done with a $\mathrm{Ge}(\mathrm{Li})$ detector and a pulse height analyzer 7 days and 40 days after irradiation.

Results obtained are presented in Table 3 and the data are plotted in Fig. 3. It is observed that REE and $\mathrm{Ba}$ patterns in the Eastern and Western mass pillow lavas are different from each other. The former shows "Solid type" (TANAKA, 1977) and the latter "Liquid type" (TANAKA, 1977), respectively.

The REE data introduced here have made clearer the contrast between the pillow lavas from the two masses mentioned above. Further studies on REE and trace elements distributions in the Jurassic greenstones of the Tokoro Belt may provide more important information on the

Table 3. Trace element abundances in the pillow lavas from the northern Tokoro Belt (in ppm)

\begin{tabular}{ccccccccccccc}
\hline & Sc & Co & Ba & La & Ce & Sm & Eu & Tb & Yb & Lu & Hf & Th \\
1 & 33.9 & 46.3 & 309 & 8.71 & 24.6 & 6.36 & 2.33 & 1.39 & 2.95 & 0.46 & 5.26 & 3.07 \\
2 & 51.0 & 62.2 & 529 & 34.3 & 73.8 & 9.53 & 3.05 & 1.39 & 1.92 & 0.29 & 4.61 & 0.99 \\
\hline
\end{tabular}

1: Pillow lava from the Eastern Mass

2: Pillow lava from the Western Mass 
origin of the Tokoro ophiolite.

Acknowledgements-We sincerely thank Prof. K. TOMURA and Dr. Y. TAKAMI of Rikkyo University for aid in INAA. The financial support of the Rikkyo Reactor Committee of University of Tokyo is gratefully acknowledged.

\section{REFERENCES}

BAMBA, T. (1984) The Tokoro Belt, a tectonic unit of the central axial zone of Hokkaido. J. Fac. Sci., Hokkaido Univ., Ser. 4, 21, 21-75.

FlanaGAN, F. J. (1969) U. S. Geological Survey Standards-II. First complication of data for the new U. S. G. S. rocks. Geochim. Cosmochim. Acta 33, 81-120.

KoSHIMIZU, S. (1984) Investigation of pyroclasticflow deposits by instrumental neutron activation analysis (INAA). Chem. Geol. 42, 307-317.

TANAKA, T. (1977) Rare earth abundances in Japanese Paleozoic geosynclinal basalts and their geological significance. Chishitsu Chosasho Geppo 28, 529-559. 